\title{
The Importance of Public Relations in the Creation of Destination Brand: Sample of Nevsehir
}

\author{
Unal Cimcek, Selin \\ Pamukkale University, Honaz Vocational School, \\ Marketing and Advertising Department, Turkey
}

Doi: 10.19044/esj.2017.v13n32p21 URL:http://dx.doi.org/10.19044/esj.2017.v13n32p21

\begin{abstract}
Today, to be able to become a destination brand our cities give a great deal of importance to distinguish themselves with their local-cultural values, identities and images. Public relations have significant contribution to the identification of a location as the destination brand which is introduced publicly. To ensure the attraction of tourists, the recognition of cities and their featuring in news is supplied through popular media and public relations strategies.

As a destination of touristic city Nevşehir with its unspoiled nature, historical and cultural attractions, attracts the attention of visitors. In this study, in the process of the creation of Nevşehir destination branding, the importance of public relations and their practices will be analyzed.
\end{abstract}

Keywords: Destination branding, Public relations, Nevşehir, Image creation, The image of the city

\section{Introduction}

In today's increasingly competitive environment, it was observed that like enterprises, cities too have differentiated with their distinctive features by entering into branding studies as destination centers. Cities position themselves in a different way and strive for branding as a means of separating from their competitors.

Every city is in a competition of getting a share from the world welfare. The purpose is to be referred and remembered better, to be visited, and thus to increase the reputation and the income of that city. The brand is the only goal and the most important task of marketing studies, because the surplus value, in other words the profit is in branding. Brand means being selected. For this, it is crucial to keep a positive, action-oriented place in the minds of people. In other words, it is necessary to do positioning (İlgüner, 2006: 117-118). 
Public relations studies have a great duty in destination brand creation process of cities; in creation of their images, in the process of ensuring them to remain in memory with the associations defining the province. Public relations carry out marketing oriented communication studies in the creation of destination brand by transmitting designated messages to the target audience with the convenient communication tools.

In this study, suggestions concerning the public relations activities, which have a great importance in brand creation process, were offered by laying the emphasis on the importance of the public relations studies in the positioning of Nevşehir, one of the unique tourism paradises of Turkey with its towns, where intertwined history and nature exhibit a holistic beauty, and its cultural accumulation enriched by the civilizations lived in the region, as a destination brand.

\section{The concept of destination The defination of destination}

A destination can be described as a geographical location that has various touristic assets and features, and can offer some or all the touristic products that the tourist might need during the trip (Atay, 2003:3).

According to another definition, destination is a whole in which integrated and coordinated studies of the tourist resources, touristic attractions, infrastructures, tools, service providers, other support sectors and administrative bodies are provided together with the expected experience of the customers from the preferred destination (Pike, 2008:24).

A city or region which has the touristic attraction can be described as a destination. The characteristics of a destination are defined as follows (Gunn, 1988: 55).

Natural Environmental Features and Processes

This contains topography, mountains, lakes, rivers and sea, soil, vegetation, daylight, precipitation, photosynthesis, erosion and other environmental processes.

\section{- $\quad$ Economic Structure and Economic Development}

This includes the level of economic development, the diversity of economic bases, spatial characteristics of development, investment partners and importexport characteristics of destination income.

- $\quad$ Social Structure and Organization

This category includes the demographic profile of the host population, the power of the local culture, the presence and the quality of social comfort, female work force, regional relations, moral behavior, security and health levels, perceptions, attitudes and values towards the tourist, language and traditions, gastronomic diversity.

Political Organizations 
The political structure and specific official authorities of the host country are significant. Law regulations can be stated as the impact of national, regional and local destination management organizations on tourism through promotions and restrictions.

- $\quad$ The Level of Touristic Development

The impact of local participation in the tourism industry involves the nature and diversity of attraction destinations, the variety and quality of places to accommodate, the entertainment and eating possibilities and the roles of travel agents.

\section{Destination types}

The place stated as a destination could be a country as well as a city, or a town. The tourism region called as destination, can also be interpreted as a perceptual concept by the customers based on their travel programs, cultural backgrounds, purposes of visit, educational levels or past experiences. Places to where the tourist leaves his residence and goes for a vacation or a business trip are as a whole defined as 'destination' (Bahar and Kozak, 2005:77).

Touristic destinations can be convened into six groups (Pekyaman, 2008:8):

1. Ethnic Tourism and Ethnic Destinations: They are sightseeing trips to examine and observe the lifestyles of interesting communities.

2. Cultural Tourism and Cultural Touristic Destinations: They are the trips people take in order to see the regions remaining in their memories and observe the almost extinct forms of life again. They desire to eat in rural regions, to participate in region's festivals, to see and examine its handicrafts.

3. Historical Tourism and Historical Touristic Destinations: It is the tourism which is made with the intention of seeing the touristic places and assets which are full of history and taking cliché cathedral trips with guides.

4. Environmental Tourism and Environmental Touristic Destinations: They are the sightseeings made by people for the purpose of returning to nature, comprehending the human-earth relationship or gaining sensitivity against it.

5. Entertaining (entertainment oriented) Tourism and Entertaining Touristic Destinations: They are the trips people take in order to improve their social relations, to sunbathe, to participate in sports activities, to have healing baths, to spend pleasant and relaxing time in a relaxing environment.

6. Occupational (for business purposes) Tourism and Occupational Touristic Destinations: They are trips taken for the purpose of meetings, such as congresses, symposiums, conferences and business meetings. 
A tourism destination offers similar characteristics compared to other destinations in terms of the features they contain. Therefore, it is necessary to focus on experiences and emotions that the product will create rather than itself in the marketing of the destination (Özdemir, 2008:74).

The acquired travel experience associated with a destination plays an important role in the formation of the destination brand. The brand image formed in the perception of the tourist who returns home after a satisfactory journey is much more valuable than the messages presented to the target audience and it strengthens the brand loyalty. Furthermore, the presentation of a lifestyle different from the lifestyle of the tourist who comes to destination will increase the attractiveness of the destination.

\section{Destination Branding}

With the adaptation of destinations, which are the greatest brands of tourism and travel industry, to the brand studies, attraction of more tourists to the region will be ensured and the development of the regional economy will be contributed.

The settlements run studies of creating their brands with the associations reminding their own characteristics. Tomorrow's tourist is someone who attaches importance to experiences rather than the material gains, who looks for local-specific experiences, and who is ethically sensitive in consumption (Yeoman et al., 2006: 184-186).

\section{Destination Branding}

1. Supporting the creation of names, symbols, logos, verbal signs and other graphics which define a destination and easily distinguish it from others,

2. Especially being related with the aforementioned destination, steadily transmitting the expectation of the travel experience worth remembering,

3. Providing an emotional connection between the visitor and the destination and reinforcement of it,

4. Reducing the research cost of the consumer and the perceived risk

The marketing activities listed above all of which are done for the purpose of creating a destination image that will positively influence the consumer's choice of destination constitute destination branding. As it is also understood from the definition, the main aim of the destination branding is to create a destination image that will positively affect the consumer's destination selection (Blain et al., 2005: 337).

For an effective differentiation, destination brands need to be remarkable and constitute emotional relationships with consumers through planned communication campaigns and public relations strategies. The branding of tourism destinations is also concerned with the establishment of 
the reputation of the settlement. Establishing and sustaining a positive perception about the city / region is carried out through public relations programs.

\section{The branding of cities}

Cities are always a brand in the world's real perception. Unless someone lives in a particular city, or has valid reasons to have knowledge of the city, that person probably produces anticipations and stories about many of the qualities and characteristics of that city. A simple brand story can have a profound effect in the decision of someone to visit a city, to purchase its products and to do business or even settle there. Paris is love, Milan is fashion, New York is energy, Washington is power, Lagos is lawlessness, Barcelona is culture, Rio is fun. These have become the brands of cities and they are inseparably linked to history and fate of those cities (Anholt, 2006: 18).

When it comes to city marketing, a city faces with a range of important options. There are four main strategies for attracting visitors, new settlers and investors, and increasing the export.

1. Image Marketing

2. Attractiveness-Attraction Marketing

3. Infrastructure Marketing

4. Person Marketing

\section{Image Marketing}

Without a unique and distinctive image, it would be difficult even for a place of attraction to draw attention in the competition-intensive market. One of the goals in image marketing is to develop a convincing and verifiable rational slogan. For instance, Ireland is using the slogan 'Celtic Tiger' to describe the successful economic development it has shown since 1995. Although Ireland constitutes only one percent of the European population, it has attracted a quarter of the US funds received by Europe. More than one thousand overseas companies have chosen Ireland as their headquarters.

\section{Attractiveness-Attraction Marketing}

Improving its image is not enough to increase its attractiveness. Cities must invest in certain attractions. Some places are lucky for having natural charms. Venice is one of them. Stockholm has also been attracting attention with its coasts and 24,000 islands, and even calling itself 'Beauty on the Water' or 'Venice of the North'. Furthermore, it is also possible to always keep the water clean, to enter the sea from inside the city, to catch fish. Each year, 'Stockholm Water Festival' is being organized. Istanbul Strait also enriches the city of Istanbul. 


\section{Infrastructure Marketing}

Streets, ring roads, airlines, railways and telecommunication networks are the most commonly seen infrastructure investments. City marketers also differentiate with their investments on the field of informatics. Being accessible, having a widespread transportation network are among the important elements of destination.

\section{Person Marketing}

It is important to use celebrities in the promotion of the city. Salzburg markets the city where Mozart was born and lived, Prague; the homeland of Franz Kafka, Liverpool; the birthplace of Beatles, Genoa; the name, memories and reputation of Christopher Columbus. Sportsmen and sports clubs also make many places to gain an identity. Madrid means Real Madrid, Milan means Milan or Inter, and Manchester means Manchester United. Local leaders, business people, and politicians also have importance in promotion of that destination.

An idea can be developed on the ten basic charm elements in the branding of cities. Public relations strategies created by utilizing this element. İlgüner and Asplund listed these strategies as follows:

1. Natural beauty and features

2. History and important figures

3. Shopping locations

4. Cultural events

5. Entertainment and recreation

6. Sports fields

7. Festivals

8. Monumental constructions

9. Museums

10. Others

DEP TATE, a branding specialist, defined the brand building process at the 3rd National Marketing Communications Congress held in Antalya in March 2012 as follows:

- You should learn what your target groups of people think about your city and conduct a survey of their perceptions.

- What does your city want to be famous for? You should find a clear answer to the question.

- You should specify the symbol of your city. Because a city can only be famous if it has its symbol. The symbol of New York is neither the monument of freedom nor the skyscraper. It is the apple. London's symbol, on the other hand, is not the Big Ben, but the 'London Eye' ferris wheel. The symbol doesn't necessarily have to tell much, it is enough for it to be simple, plain, and cute. 
- Shooting of a world-famous or country-wide barnburner series or movie in your city is important in branding.

Your city might make a name for itself through an organization, such as Olympics, international or national festivals.

In the process of creating a brand, it is very important to find out the essence of the city and transmit it to the groups of targeted people by convenient communication channels and planned public relations campaigns. Public relations tools, photos, brochures, catalogs, internet and social media can be benefited from in promotions. The incredible development of social media networks has made it easier for cities to communicate with social media users.

Social media provides important opportunities for tourists to search for information about their destination choices and to choose places to accommodate. Today, the internet and social media emerge as an important tool of mass communication in terms of reaching the target groups and with regards to the choice of accommodation destinations by tourists.

It has become one of the main sources of researching for individuals before making any decisions on tourism issues. The studies carried out accordingly confirm the impact of social media on the tourism sector. One of these studies carried out by Google Traveler Study in 2014 revealed that $68 \%$ of travelers were searching for information online before choosing places to go and deciding how to go there. And the study of TripAdvisor in 2013 detected that almost two-thirds (\%61) of US vacationers used social media as a means of obtaining information during their holidays. According to the study named Trip Barometer made by TripAdvisor in 22 countries in 2013, it was also confirmed that $87 \%$ of vacationers around the world were actively using their smartphones during their vacation, and the main reason for this was the need to access the tourist informatics online (Eşitti and Işık, 2015: 1-19).

\section{Public relations}

\section{The concept of public relations}

The satisfaction and fulfillment of the needs and desires of individuals depends on the mutual involvement of individuals, companies, institutions and organizations. Public relations in this regard has an important role in establishing and managing the relations between people and organizations (Tengilimoğlu and Öztürk, 2011:21).

In a broad sense, public relations can be defined as all the efforts that an institution spends towards integration into society. However, the segment of the public every institution has relations with offers differences. For example, public includes all the people living in the country for a government, its own members for an association, its own readers for a newspaper, its own supporters for a sports club, employees within the organization and all the 
people and organizations located outside but related to the company for an enterprise (Sabuncuoğlu, 2010: 3-4).

According to the definition made by the International Public Relations Association (IPRA), public relations is a continuous and well-organized administrative function that aims to infuse a business into employers, executives or customers by using the principles of honesty, credibility and reliability, and to gain their understanding, sympathy and support (Aydede, 2002: 178).

Sabuncuoğlu (2010) summed up the meaning of the public relations concept as follows:

- Public relations is a management function.

- It is a communication phenomenon.

- It is a process of influencing and directing the public opinion.

- It is a planned and well-organized study.

- It is the events organized by the enterprise in the framework of social responsibility.

- It is the integration of the institution with the society.

- It is the formation and development of the corporate image.

When evaluated with this approach, public relations contain a wide array from diplomatic communication in international relations and lobbying activities being held to ensuring of the participation of the citizens in the governance and decisions, from the efforts of non-governmental organization to get support, to marketing communications of enterprises, to democratic participation of employees, and from international relations up to the communication with the employees.

Public Relations objectives must perpetually be in harmony with the institutional objectives. Thus, the institutional objectives must also be determined in advance. One of the tasks performed in the planning is the determination of the communication contents. The basic point here is that all the contents must be in accordance with the facts. Because inaccurate and unclear contents will damage the goal of improving the image, which is one of the main objectives of the public relations, within a certain period of time (Okay and Okay 2011: 239).

\section{Corporate public relations}

The purpose of corporate public relations is; to develop and preserve the institution's image, and to create a strong institutional image reassuring the community. To this end, it works with the senior management to determine the mission and vision of the institution, and organizes various events for the public to know and understand the values of the institution. In accordance with a predetermined strategy, it ensures that the communication of the institution 
with all its target groups is implemented with the principle of "right time, correct group, correct message" (Paksoy, 1999: 44).

Corporate public relations use a bi-directional communication process when communicating with the target audience. And to perform this bidirectional communication it uses home media communication channels. Corporate public relations perform the following functions in general (Sezgin, 2007: 19).

- Suggestion and counseling

- Corporate publications

- Publication about the institution

- Relations with society

- Corporate image oriented advertisement and messages

- Creating and influencing public opinion

- Programs with social content

\section{Marketing-oriented public relations}

Marketing-oriented public relations are public relations supporting the marketing activities with the intention of increasing the sales of the organization in line with marketing strategies. Marketing-oriented public relations involve product-oriented activities as opposed to institutional public relations (Sezgin, 2007: 20).

Sezgin (2007) listed the activities of Marketing-Oriented Public Relations as follows:

- Helping the promotion of new products,

- Promoting the existing products,

- Positioning the enterprise as the expert and leader in its field,

- Reinforcing the interest of the consumers in the product, gaining their trust,

- Creating a strong corporate image that supports the product (Supporting the corporate public relations activities for this purpose)

- Being prepared for possible crises or reducing the negative effects of the crisis period to the least,

- Constituting new markets, reaching secondary markets or supporting the weak markets,

\section{Target audience in public relations}

In terms of public relations, the groups who have direct or indirect ties to the organization constitutes the public. In other words, all parties that the organization must deal with form the target audience (Peltekoğlu, 2009: 167). They can be defined as the persons or the groups from whom changes of actions and thought are expected as a result of these activities directed by the institution (Pira, Baytekin, 2007: 96). 
Target audience will also be different according to the area where each institution and corporation operates. It might even experience change of target audience in the process. When communicating with these different types of target groups, Public Relations experts also carry out the function of "recognition and promotion" which is the basis of public relations. Knowing the socio-economic status and the demographic features of the target audience, it will follow strategies and public relations policies appropriate to these, and will gain the sympathy and interest of the public.

The aim of an institution and the public relations studies performed by an association is to inform the target group about the studies conducted in the public opinion. Public opinion which is defined as community of people with common interests is affected by people and various groups. In order to create a positive opinion in people about the institutions, it is necessary to give timely and accurate information (Okay and Okay 2011: 210).

In today's conditions, it is not possible for an institution to perform public relation strategies without communicating with the target audience, without learning and researching their thoughts.

The main target groups of an organization are collected under eight titles by Frank Jefkins:

- Corporate Environment

- Employees

- Potential Employees

- Suppliers and Service Providers

- Investors-The Money Market

- Distributors

- Consumers and Ultimate Users

- Opinion Leaders

By determining the target audience in an accurate and detailed manner, we can detect all groups related to the campaign in advance, balance the budget and resource usage, choose the right communication tools and techniques, and prepare the active message.

\section{Tools and methods used in the public relations}

In order to reach their target groups as effectively as it is required, Public Relations Experts need to use communication tools and techniques in a coordinated manner.

Press, which has a very high impact on people and organizations, has a great power in the creation of public opinion within a specific subject frame, in the manipulation of the public opinion in a positive or negative way. When having good relations with the media provides great advantage for the institution, negative relations can subject institutions to crises that can't be reversed (Göksel, 2010: 114). 
Traditionally, relations with the press is one of the main tasks of public relations. John McManus and Doug Underwood stated that the information provided by the public relations units is also seen more valuable by the media, and success chances of the public relations campaigns announced through mass media tools rises further in case of an increase in economic pressure on the media (Okay and Okay 2007: 23).

In relations with the press, the production of news is carried out through various tools. These tools include press releases, press tours, press conferences, compilation of clippings, and interviews.

We can examine the tools we use in Public Relations in four groups: Printed tools, verbal tools, visual and auditory tools and organizational tools.

The newspapers, magazines, brochures, handbooks, posters, banners, annual activity reports, letters, stamps are in the group of printed tools. They are preferred for their features such as their availability of being stored, reevaluated, and presented as evidence

Oral tools, on the other hand, contain; face-to-face interviews, meetings, congresses, symposiums, and conferences.

In the group of visual and auditory tools; there are television, radio, film, multimedia, social media, internet. For blogs and social networks are both fast, directly orientable to the target audience, and more economical, they are the preferred tool in public relations campaigns.

As organizational tools exhibitions, fairs, openings, festivals, competitions, anniversary events are regarded as appropriate tools in public relations campaigns.

Fulfilling the function of promotion, public relations provide the opportunities of informing and presenting its enterprise and brands to the target audiences with the help of mass media.

\section{The role of public relations in branding}

The importance and influence of public relations activities is great in all processes such as brand creation, branding, brand placement, ensuring the sustainability of the brand. Public Relations activities provide and enhance the reputation of institutions in the long run. On the reputed structure, ensuring the sustainability of organizations, and creating new brands would be much more permanent.

During the branding period, the public relations must be your greatest guarantee. The role of the public relations in branding also gains importance at this point. Provision of the branding with advertisement can be implemented up to a point. However, it is never enough for the brand to be promoted and sustained. Crises can arise in institutions which do not govern these processes through communication, even if it is a world brand. Local differences are gaining importance. In communication studies, the management of 
communication activities according to the local language, style, and social characteristics of the local target group absolutely contributes to the brand's distinctiveness. Executives who concentrate on public relations in the branding process consolidate the future of their organization (www. fugentoksu.com/2011/07/06).

Public relations activities are being benefited from in order to successfully create the destination brand and to preserve the brand's image.

\section{Nevşehir in the scope of the destination branding}

The province of Nevşehir differs from the other provinces by its interesting geographical formations. The fact that the soil can be easily carved, led to the formation of a rich settlement culture in Nevşehir. Today, a large number of structures especially built by Christians, who settled here in the middle ages, through carving the land for shelter and worship, have led Nevşehir to become a large open-air museum. Natural and historical riches in the region are mostly centered in the Avanos-Nevşehir-Ürgüp triangle. The 9.576 hectare area ,which is in this part of the province, was taken under protection as Göreme Historical National Park on 25 November 1986 (http://www.bilx.net/form/turkiye-illeri/nevsehir-ili-tarihi-ve-nevsehir-sehrihakkinda-bilgiler/) Nevşehir, which has one of the most fascinating atmospheres of the world with its fabulous scenery and unique nature, has hosted numerous civilizations throughout the history of mankind. The worldfamous fairy chimneys are what instantly comes to the mind when the name of Nevşehir providence, whose income from tourism increases each year and where many new touristic buildings were constructed, is mentioned. In addition to its interesting geological structure such as fairy chimneys, the settlements carved on rocks are rare, natural, and cultural centers.

There are many nature sports facilities in the region, including hot air balloon, trekking, mountain bike, and horse safari. Cappadocia, registered as "Göreme Natural and Historical National Park" in 357th place in UNESCO World Natural and Cultural Heritage List in 1985, is rightfully inherited its unique place in the world with its natural structure and cultural diversity.

According to the destination descriptions made, it can be said that Nevsehir is a tourism destination. Because Nevşehir hosts attractive natural attractions for tourists. It has a great wealth of history nature and culture. In addition to being attractive, destinations must have a mixture of products and services such as the presence of image, transportation, accommodation, eating and drinking, parks, museums, ruins and similar entertainment-leisure facilities (İlban, 2007: 6-7).

We can offer our suggestions on what can be done about public relations studies in the branding process of the region by conducting a SWOT analysis on Nevşehir province and Cappadocia region. 


\section{Strengths}

- Being a tourism city on the internationally recognized UNESCO World Natural and Cultural Heritage list

- Diversity in tourism area (valley tourism, hot air ballooning, village and farm tourism, cross-golf, trekking, congress tourism)

- The presence of historical, natural, cultural diversity.

- Business opportunities with diversity of agriculture, tourism, geothermal energy resources

- The preserved urban texture

- Visits of a large number of tourists from Christian and Orthodox worlds to Nevşehir with the intention of worshiping

- Having Kozakl1 water as one of the most important thermal waters in Turkey and in the world with its high temperature, ion content and volcanic features

- Having the world-famous Turkish philosopher, Hacı Bektaş and Damat Ibrahim Pasha, the grand vizier of the Ottoman period, lived in this region.

- Accessibility by land, sea, and airlines

- Availability for tourism during twelve months of the year.

- The love and respect of the local people against nature

- The presence of a university in Nevşehir

- Nevsehir to have a symbol (fairy chimneys)

- Having films and series shot in the city and in the region

- Having many festivals performed in the region

- Purporting a modern city with the infrastructure and superstructure works.

- Presence of a story evoking the name of the city / region and a differentiation arousing curiosity

\section{Weaknesses} tourism

- Having the airport renovated during the most vibrant period of

- Deficiencies in the worldwide promotion

- Giving no place to the story associated with the name of the city / region, to the curiosity arousing differentiation in promotions.

\section{Opportunities}

- International recognition of Nevsehir

- Natural beauty of Nevşehir

- Good social and cultural structure of Nevsehir

- The developing tourism sector

- Having more tourists to visit Nevsehir each year 
- Having good city transportation facilities

- The existence of alternative tourism areas

- The presence of two universities, many faculties and schools in the city

- The cultural richness, and having people of different religions and beliefs live together.

- The existence of Nevşehir Sustainable Tourism and Development Plans

\section{Threats}

- Absence of the tourist due to the security problems of the country

- Irregular urbanization

- Lack of industrial investments

- Intensive construction

- Infrastructure problems

- Airport transportation problems

- Unqualified personnel in tourism

As it is also seen in the analysis done, Nevsehir's strengths and opportunities are predominant. Weaknesses and threats, on the other hand, are less, yet not at the minimum. By increasing the strengths and minimizing the weaknesses, we would have a positive effect on the image of Nevsehir and contribute to the destination branding.

\section{Conclusion and proposals}

My suggestions on the creation of the Nevşehir destination brand for public relations activities are presented below. Contribution to the creation of Nevşehir brand perception can be provided with the support of the other local authorities, particularly the municipality and the governorate.

- One of the necessary elements to become a brand is "mystery". Intriguing, magical, different destinations are attraction centers for tourists. When looked into the writings and resources written about Nevşehir up to this day, because of the fairy chimneys, there are mythological stories about that the underground cities were created by fairies or constituted by aliens, and that giants lived there. The underground cities built 6-8 times below the ground with enormous engineering marvel aeration systems and logic, are mysterious places for tourists. When Nevşehir province, where the brand fiction is created by the magical and mysterious stories, is also supported by its natural and historical beauties, blogs describing the city, web sites, social media and promotional films, the attractiveness of the destination brand will be increased for the visitors.

- The international promotion of Nevsehir, which is on the UNESCO World and Cultural Heritage List, must be transferred to the target audiences 
via the mass media, together with the Ministry of Culture and Tourism, with support from the newly established "publicity fund" within the Ministry of Economy, through the stories to be built on the theme of "mystery" and the supporting slogan.

- When we think of press relations' importance in public relations, especially the subject regarding the mystery of the underground cities inhabited by different civilizations can be supported for the international press through news studies.

- Nevşehir promotional films and blogs should be prepared with the slogan completes the perception of the city, and the mysterious story of the city.

- Press releases about the city and the region should be prepared for national and international press in certain periods.

- There should be a website prepared in different languages, introducing the city with the possibility of finding all the information about it.

- Individuals are able to easily access the information about tourism companies and share their experiences about the services offered to them by interacting with each other through social networks and websites like TripAdvisor. Public relations have important duties in the management of the websites which are so effective in individual's destination preferences, and in answering of the questions and sharing the views.

- One of the important elements when creating perception about Nevşehir is the image. The corporate identity and its logo, colors, printed materials, exterior and interior images are important in the image of the city. The symbol associated with the city should be created within its corporate identity. Cities with corporate identity can create brands.

- A picture-laced church, which is said to belong to the 5th century B.C., was found in the excavation and cleaning work done in the underground city revealed during the Kale and Its Surroundings Urban Transformation Project carried out by Nevşehir Municipality and Housing Development Administration. The frescoes depicting the rise of Jesus to the sky and the murder of evil spirits inside the church were encountered in the church. Promotional work can be done about this church, which evokes excitement for the Christian world. Opening of the rock-hewn church under the ground to tourism could turn Cappadocia into a place where orthodox people would perform the pilgrimage worship. This situation will bring Nevsehir and Cappadocia region to a very different position as a brand. It strengthens the sense of destination brand with internationally promotional activities.

- Public relations projects should also be developed for the local community, which is the internal target audience of Nevşehir. Trainings of communication, human relations, marketing, team work, service 
compensation, brand image, entrepreneurship etc. should be given to the local community and to the team in charge of branding.

- The importance of film series composed of folk tales, cultural items, and mythological assessments is great for Nevşehir to gain ground in the minds as a destination brand. Initiatives can be made for shooting a film featured by world-renowned artists in Nevsehir, the mysterious city gained attraction for the tourists with the "Asmalı Konak" series broadcasted in 2002.

Based also on the continuity principle of public relations, it is necessary to continue these proposed studies, to add new projects. The perception of the destination brand will be strengthened with the implementation of the branding process together with local administrations and professional teams.

\section{References:}

1. Anholt, S. (2006). The Anholt-GMI city brands index: How the world sees the world's cities. Place Branding, 2(1), 18-31.

2. Atay, L. (2003). Destinasyon pazarlaması yönetimine ilişkin stratejik bir yaklaşım. Dokuz Eylül Üniversitesi İşletme Fakültesi Dergisi, Cilt IV, Say1 2.

3. Aydede, C. (2002). Halkla ilişkiler kampanyaları. İstanbul: MediCat.

4. Bahar O., Kozak, M. (2005). Küreselleşme sürecinde uluslararası turizm ve rekabet edebilirlik. Ankara: Detay

5. Blain C., Levy S.E., Ritchie, J.B. (2005). Destination branding: Insights and practices from destination management organizations. Journal of Travel Research, 43(4), 328-338.

6. Eşitti, Ş., Işık, M. (2015). Sosyal medyanın yabancı turistlerin Türkiye'yi tatil destinasyonu olarak tercih etmelerine etkisi”. Karadeniz dergisi, 27, 1-19.

7. Göksel, A.B. (2010). Stratejik halkla ilişkiler yönetimi. Ankara: Nobel.

8. Gunn, C.A., (1988). Vacationscape-desinging tourist region. Second edition. New York: Van Nostrand Reinhold.

9. İlban, M. O. (2007). Destinasyon pazarlamasında marka imajı ve seyahat acentalarında bir araştırma. Yayınlanmamış Doktora Tezi, Balıkesir Üniversitesi Sosyal Bilimler Enstitüsü, Balıkesir.

10. İlgüner, M. (2006). Türkiye'de marka yaratma ve yaratmanın altın kuralları. Ankara: Rota.

11. İlgüner M., Asplund C. (2011). Marka şehir. İstanbul: Marketing.

12. Okay A., Okay A., (2007). Halkla ilişkiler ve medya. İstanbul: MediaCat.

13. Okay A., Okay A., (2011). Halkla ilişkiler kavram strateji ve uygulamalart. İstanbul: Der.

14. Özdemir, G. (2008). Destinasyon pazarlaması. Ankara: Detay. 
15. Paksoy, A. (1999). Türkiye'deki halkla ilişkiler uygulamaları. İstanbul: Rota.

16. Pekyaman, A. (2008). Turistik satın alma davranışında destinasyon imajının rolü: Afyonkarahisar bölgesinde bir araştırma. Basılmamış doktora tezi. Afyon Kocatepe Üniversitesi Sosyal Bilimler Enstitüsü, Afyonkarahisar.

17. Peltekoğlu, F. (2009). Halkla ilişskiler nedir?. İstanbul: Beta.

18. Pike, S. (2008). Destination marketing-An integrated marketing communication approach UK: Butteworth-Heinemann.

19. Pira, A., Baytekin, P. (2007). Halkla ilişkiler: Neyi nasıl yapmalı?. İstanbul: Dönence.

20. Sabuncuoğlu, Z. (2010). İşletmelerde halkla ilişkiler. Bursa: Alfa Aktüel.

21. Sezgin, M. (2007). Halkla ilişkiler. Konya: Yüce Medya.

22. Tengilimoğlu, D., Öztürk, D. (2011). İşletmelerde halkla ilişsiler, İstanbul: Seçkin.

23. Yeoman, I., Munro, C. and McMahon-Battie, U. (2006). Tomorrow's: World, consumer and tourist. Journal of Vacation Marketing, 12(2), 174-190.

24. www. fugentoksu.com/2011/07/06

25. www.bilx.net/form/turkiye-illeri/nevsehir-ili-tarihi-ve-nevsehir-sehrihakkinda-bilgiler 